\title{
Effect of management on natural capital stocks underlying ecosystem service provision: a 'provider group' approach
}

\author{
F. J. F. Maseyk ${ }^{1,2}$ (D) L. Demeter ${ }^{3}$ - A. M. Csergó ${ }^{3,4}$. \\ Y. M. Buckley ${ }^{2,4}$
}

Received: 19 August 2016/Revised: 21 July 2017/Accepted: 5 August 2017 / Published online: 23 August 2017

(C) The Author(s) 2017. This article is an open access publication

\begin{abstract}
Land management practices directly impact on the occurrence and condition of natural capital stocks, which can be measured using species diversity and abundance metrics. Species identity and abundance drive ecosystem service supply, either through effects of local diversity and/or through the presence of service providing species. However, the influence of management practices on the provision of ecosystem services is not adequately understood. We grouped grassland plant species into six groups according to desirable attributes (palatability and nutritional value to livestock; medicinal or aromatic compounds; nectar production; pollen production; nitrogen fixation; and endemic and red listed species), which we recognise as ecosystem service 'provider groups', and tested the
\end{abstract}

Communicated by Astrid van Teeffelen.

A. M. Csergő and Y. M. Buckley joint-senior authorship.

This article belongs to the Topical Collection: Biodiversity exploitation and use.

Data accessibility: Raw data, full species lists and R scripts are available from the Dryad Digital Repository: http://dx.doi.org/10.5061/dryad.97cj5.

Electronic supplementary material The online version of this article (doi:10.1007/s10531-017-1406-9) contains supplementary material, which is available to authorized users.

F. J. F. Maseyk

f.maseyk@uq.edu.au

1 School of Biological Sciences, Centre for Biodiversity and Conservation Science, The University of Queensland, Brisbane, QLD, Australia

2 ARC Centre of Excellence for Environmental Decisions, The University of Queensland, Brisbane, QLD, Australia

3 Misgurnus Association, Str. Johannes Kájoni 67, 530204 Miercurea-Ciuc, Romania

4 Department of Zoology, School of Natural Sciences, Trinity College Dublin, College Green, Dublin 2, Ireland 
influence of three land management practices (abandonment of mowing, grazing, and mowing) on diversity and abundance within these groups in upland temperate grasslands of Transylvania (Romania). All three management practices favoured at least one provider group, but hay making in upland grasslands favoured more provider groups than abandonment of mowing or grazing. The effects of management on diversity and abundance within several provider groups diverged from the effects on overall species diversity and abundance. Management, through changes in species composition, favours certain provider groups, and hence ecosystem services, over others. The provider group approach is more useful than overall species diversity metrics for assessing the provision of ecosystem services from landscapes and can be used to inform the development of agri-environment schemes and conservation policies aimed at meeting priorities for ecosystem service provision.

Keywords Carpathian Mountains · Grassland management · Mountain hay meadow $\cdot$ Multifunctionality $\cdot$ Species diversity $\cdot$ Traditional land use

\section{Introduction}

Species richness and diversity metrics are commonly used as proxies for ecosystem function and ecosystem service provision (Byrnes et al. 2014). More diverse systems are thought to increase the number, amount, and temporal stability of ecosystem functions and services by providing both greater functional redundancy (multiple species contributing similarly to the same function or the same ecosystem service) and response diversity (variability in response to disturbance or changed environment conditions between functionally similar species) (Díaz and Cabido 2001). Consequently, more diverse systems are more likely to contain species possessing traits that contribute to given functions and services year to year (Allan et al. 2011) and to more resilience (the simultaneous resistance to and recovery from disturbance, Hodgson et al. 2015) thus providing 'functional insurance' (Díaz and Cabido 2001; Laliberte et al. 2010; Isbell et al. 2011; Hautier et al. 2014). This provides greater stability within a biophysical system through time, which in turn contributes to sustained provision of ecosystem services and associated social benefits. Diverse systems are expected to have high multifunctionality, which is achieved when local sites or landscapes simultaneously provide multiple ecosystem functions or services (Allan et al. 2015; Byrnes et al. 2014; Gamfeldt et al. 2013; Wagg et al. 2014). Landscapes can provide a range of ecosystem services either through provision of multifunctionality at a local scale or through spatial heterogeneity of service provision due to landscape mosaics of different ecosystems and communities, which are often shaped by social preferences (Allan et al. 2015). However, the link between general diversity metrics and ecosystem service quantity, quality, and stability of provision is non-linear and often does not provide the granularity required for decision makers to make informed land management decisions.

Different land management actions affect species composition and ecosystem function, changing the provision of ecosystem services. We posit that although there are several ways in which the effects of management on ecosystem service provision can be explored, each have critical limitations in terms of understanding the direct impacts of management practices. (1) Assessing the effects of management on species diversity metrics in general, assuming that higher diversity generally will have a positive outcome on ecosystem service provision, can miss impacts of management on particular species that may be important contributors to the required ecosystem service(s). (2) Assessing the effects of management 
on individual species known to directly provide particular ecosystem services has more merit on local scales; however, multiple species often contribute to a single ecosystem service at local and larger scales and it is difficult to generalise effects where the species providing that service changes across a landscape. (3) Assessing the effects of management directly on ecosystem service provision is resource intensive and also problematic, as it ignores the natural capital stocks (the abiotic and biotic elements of nature that can be measured in terms of their quantity, quality and spatial and temporal dynamics) and ecosystem processes that give rise to those services. Thus, while a change in ecosystem service provision may be detected, the underlying drivers remain unclear. This ambiguity also makes it difficult to generalise results across landscapes.

Here we test an alternative approach by which to assess the impact of management practice on the provision of ecosystem services. In order to better understand the mechanics of the relationship between biodiversity and ecosystem function and service provision, we need to move beyond overall diversity metrics and consider functional diversity and composition (e.g. Cadotte et al. 2011; Díaz and Cabido 2001; Duncan et al. 2015; Lavorel et al. 2011; Mace et al. 2012; Naeem and Wright 2003). The advantages of focusing on functional groups rather than species richness per se are recognized elsewhere (e.g. Allan et al. 2011; Laliberté et al. 2010; Naeem and Wright 2003). Luck et al. (2009) built on earlier concepts to develop the 'service provider' concept, which provides an expanded conceptual framework for the study of the relationship between biodiversity and ecosystem service provision. Here, we build on these existing functional and service provider approaches by recognising sets of species ('provider groups') that possess particular attributes that contribute to the provision of ecosystem services either directly or indirectly. We use our provider group approach to test the impacts of management practice on the natural capital stocks that supply ecosystem services.

Ecosystem services of interest to our case study community are three provisioning services: supply of food, raw materials, and medicinal resources; a regulating service: nutrient regulation; and two cultural services: species of conservation concern, and sense of place. We identified six species attributes by which to categorise provider groups that contribute to the provision of these ecosystem services in this system: (1) palatability and nutritional value to livestock; (2) medicinal or aromatic compounds; (3) nectar production; (4) pollen production; (5) nitrogen fixation; and (6) endemic and red listed species. For example, nectar producing species were grouped together in the 'honey provider group' and considered to contribute to the provision of both food and medicinal resources. Table 1 lists the six provider groups and illustrates the link between these groups and the supply of ecosystem services. We recognise that interactions with other species (e.g. honey bees extracting nectar from nectar producing species and pollinators visiting pollen producing species), ecosystem processes (e.g. the process of pollination (pollen provider group), energy transfer/food webs (quality fodder provider group), or nutrient cycling necessary for maintenance of system function and support of fodder species (nitrogen fixation provider group), other forms of capital (e.g. financial, built, and social), and socio-political drivers are also required for the provision of ecosystem services, but the provider group approach is useful for identifying the underlying supply of ecosystem services.

We illustrate the provider group approach by testing the effects of land management on these six ecosystem service provider groups, and consequently the provision of multiple ecosystem services, using a case study from the Southeastern Carpathian Mountains in Romania. We tested how the diversity and abundance of grassland plant species within each provider group are impacted by three different land management practices: 
Table 1 Summary of species attributes used in this study to assign species into 'provider groups' for analysis and used as proxies to indicate the supply of ecosystem services

\begin{tabular}{|c|c|c|}
\hline Provider group & Species attributes & $\begin{array}{l}\text { Ecosystem service } \\
\mathrm{P}=\text { provisioning services } \\
\mathrm{R}=\text { regulating services } \\
\mathrm{C}=\text { cultural services }\end{array}$ \\
\hline Pollen & Pollen production & $\begin{array}{l}\text { Medicinal resources }(\mathrm{P}) \\
\text { Food }(\mathrm{P})\end{array}$ \\
\hline Quality fodder & $\begin{array}{l}\text { Palatability and nutritional value to } \\
\text { livestock }\end{array}$ & $\begin{array}{l}\text { Food }(\mathrm{P}) \\
\text { Raw materials }(\mathrm{P})\end{array}$ \\
\hline $\begin{array}{l}\text { Medicinal and aromatic } \\
\text { compound }\end{array}$ & Medicinal or aromatic compounds & $\begin{array}{l}\text { Medicinal resources }(\mathrm{P}) \\
\text { Raw materials }(\mathrm{P})\end{array}$ \\
\hline Honey & Nectar production & $\begin{array}{l}\text { Food }(\mathrm{P}) \\
\text { Medicinal resources }(\mathrm{P})\end{array}$ \\
\hline Nitrogen fixation & Nitrogen fixation & $\begin{array}{l}\text { Nutrient regulation }(\mathrm{R}) \\
\text { Food }(\mathrm{P})\end{array}$ \\
\hline Conservation concern & Endemic or red listed species & $\begin{array}{l}\text { Maintenance of species of conservation } \\
\text { concern }(C) \\
\text { Sense of place }(C)\end{array}$ \\
\hline
\end{tabular}

abandonment of hay meadows, grazing, and mowing (hay making) within mountain hay meadows. We then contrasted the provider group approach with overall diversity and abundance measures as coarser proxies of ecosystem service provision. Measurement of the response to management regime at the provider group level enables the rapid assessment of how land use or management practice can impact consequent ecosystem service provision. This framework can be generally applied to any system using existing species diversity data with the addition of information on provision of ecosystem services, as relevant to a local or regional setting. The results can be incorporated into decision making processes enabling stakeholders to assess effects of management on multiple services against their stated objectives and develop landscape scale management plans.

\section{Methods}

\section{Site description}

The study was conducted in two grassland systems within the Southeastern Carpathians, Romania $\left(46^{\circ} 41^{\prime} \mathrm{N}, 25^{\circ} 94^{\prime} \mathrm{E}\right)$. The Southeastern Carpathian grasslands are part of a rural landscape where local communities have continued traditional semi-subsistence farming since the Middle Ages, actively maintaining forest-free habitats for summer grazing and winter fodder (hay) for livestock (sheep, cows, goats, and horses) (Babai and Molnár 2014; Babai et al. 2015; Knowles 2011). Large grassland areas were formed following the almost complete clearance of the deciduous forest land cover below 900 masl, and the partial deforestation of spruce and mixed broadleaf-coniferous forest cover at elevations above 900 masl (Csürös et al. 1980). These historically human-induced, extensively managed grasslands represent areas of high biological diversity and habitats of important cultural 
and social value in Europe and worldwide (Knowles 2011; Wilson et al. 2012). Mountain hay meadows in particular are protected within the Natura 2000 framework of the European Union (European Commission 1992).

During the communist regime (1947-1989), agricultural intensified and stock numbers peaked. Consequently, all available grassland in the mountains was either grazed or mown for hay. After the regime change in 1989, the practice of collective farming ceased and previous family farms were re-established but total stock numbers, and thus the demand for hay, declined. The most remote hay meadows were abandoned first (Demeter and Kelemen 2012) and 'partial abandonment' also occurred with a shift from mowing to sheep grazing on good quality meadows. As a result of this environmental history, a mosaic of three dominant land cover types exists across the Southeastern Carpathians: pasture, hay meadows, and regenerating secondary forest transitioning towards mixed Norway spruce (Picea abies (L.) H. Karst.)-European beech (Fagus sylvatica L.) forests typical of the area (Fig. 1).

The first sampling site was located at Somlyó Valley (Somlyó) within the Csík Basin (Depresiunea Ciucului) and the second at Kolos, within the Csík Mountains (Munţii Ciucului) (Fig. 2). The Kolos site covered $1.8 \mathrm{~km}^{2}$ at an elevation range of 942-1292 masl and was relatively remote $(15 \mathrm{~km})$ from the nearest settlement. In contrast, the relatively lower elevation (764-802 masl) site Somlyó covered $1.3 \mathrm{~km}^{2}$ and was located within $2 \mathrm{~km}$ of the nearest settlement. Grassland communities at the Kolos site were co-dominated by common bent Agrostis capillaris L. and Chewings fescue Festuca nigrescens Lam., creating a Scorzonero roseae-Festucetum nigricantis (Puşcaru et al. 1956) Coldea 1987 community. At the Somlyó site common bent and red fescue Festuca rubra L. co-dominated creating a Festuco rubrae-Agrostetum capillaris community Horvat 1951, reflecting differences in environmental conditions between the two sites. The nomenclature of the two communities follows Sanda et al. (2008).

Hay making frequency varied between the two sites, with meadows being mown only once a year in Kolos and once or twice (but most often twice) a year at Somlyó. Temporary grazing of sheep during autumn may occur within hay meadows at both sites and lower elevation meadows may also be fertilized with manure. These are typical management

(a)
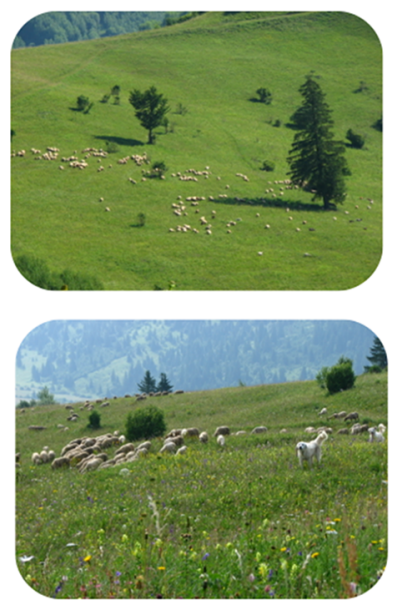

(b)
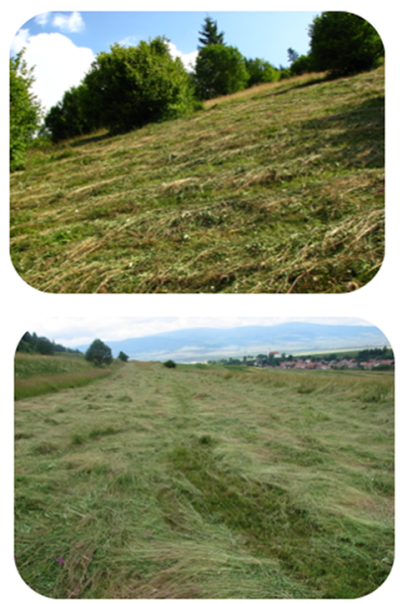

(c)
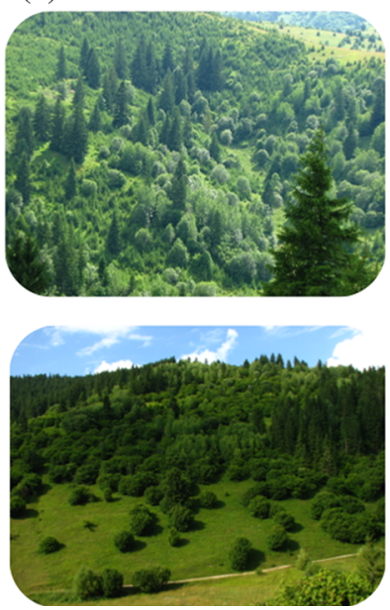

Fig. 1 The dominant land cover types within the study area associated with the three management practices gazing, mowing, abandonment of hay meadows: a pasture (grazing); b hay meadows (mowing); and c abandoned hay meadows (abandonment) and regenerating secondary forest (Photo credit: Anna M Csergö) 


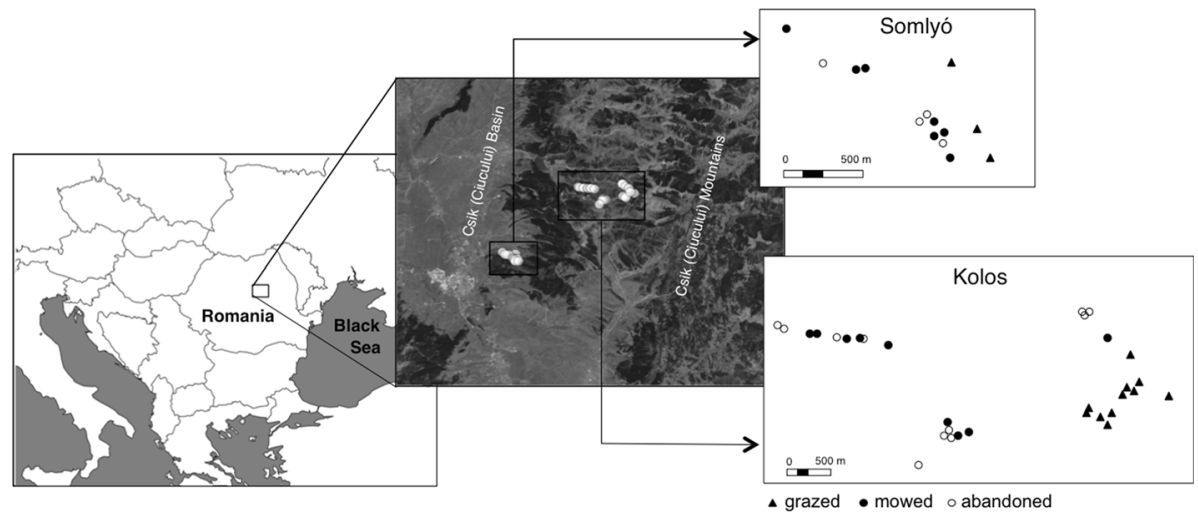

Fig. 2 Map showing the location of the study area in Romania and the distribution of the $1 \mathrm{~m}^{2}$ plots at the Somlyó (top) and Kolos (bottom) sites by management practice

regimes for hay meadows in both remote and less remote areas. Abandoned hay meadows had been unmown for between 3 and 5 years, but may be subject to light grazing by sheep. Within our study area, pastures are maintained under sustained sheep grazing.

\section{Data collection}

Within each of the two sampling sites (Kolos and Somlyó), three management practices (abandonment of hay meadows, intensive grazing by sheep, and mowing (hay making)) were identified (Fig. 2). Plots $\left(1 \mathrm{~m}^{2}\right)$ were randomly located across each management practice (grazing, mowing, and abandonment of hay meadows) with adequate frequency to capture environmental heterogeneity. A total of 31 plots were located at the Kolos site: 11 in abandoned hay meadows, 11 in pastures (grazed), and nine in hay meadows (mown); and a total of 14 plots were located at the Somlyó site: four in abandoned hay meadows, three in pastures, and seven in hay meadows. The number of plots varied due to the different sizes of sampled land parcels. Abandoned hay meadows, pastures, and hay meadows were therefore sampled with 15, 14 and 16 plots respectively (summed across sites). For each plot, a list of all species present was compiled, and abundance (percent cover) visually estimated for each species present and for total vegetation cover.

We defined our six provider groups based on the following species characteristics: pollen production; provision of quality fodder; provision of medicinal and aromatic compound; honey production; nitrogen fixation; and conservation concern (Table 1). Csürös et al. (1970) classify species according to attributes, and this publication was used to identify species possessing palatability and nutritional value to livestock; species producing medicinal or aromatic compounds, nectar, or pollen; and species with nitrogen fixation attributes. We considered species listed as 'excellent', 'very good' and 'quality' fodder plants to posses palatability and nutritional value to livestock. In addition, we identified species of conservation concern (endemic or red listed species) from a regional list of endemic and protected plant species (G. Jakab and A. Csergő pers. com) which was based on the national red list of vascular plants and the national checklist of plant species of Romania (Oltean et al. 1994; Oprea 2005) and unpublished data. Sampled species were 
assigned to as many of the six provider groups for which they possessed the described characteristics (attributes).

\section{Data analysis}

The response variables were (1) species richness (number of species), (2) species evenness (Evar; Smith and Wilson 1996), (3) species diversity (Inverse Simpson Diversity [=1/Simpson's diversity)], and (4) relative abundance within each $1 \mathrm{~m}^{2}$ plot for each provider group, calculated using the vegan package (Oksanen et al. 2013) in $\mathrm{R}$ (all analyses were performed in R.3.2.3, R Core Team 2015). We calculated the relative abundance of each species by dividing its abundance by the total vegetation cover of all species within the plot and we subsequently summed these by provider group. In order to compare our approach to other approaches which directly use species diversity metrics as a proxy for ecosystem service provision, we also calculated the same metrics comparatively over individual provider groups and over all species within each plot. We tested for significant differences in our response variables across management practice (abandonment of hay meadows, grazing, and mowing,) and sites (high elevation Kolos and lower elevation Somlyó) for each provider group. Pastures were spatially segregated within sites so we analysed the data according to a randomized complete block design with subsampling (RCBs), in which the two sites represented blocks, the three treatments (management practices) were spatially segregated within each block, and the $1 \mathrm{~m}^{2}$ plots represent subsamples within each treatment. We fitted linear mixed effects models (LMMs) in which both management practice and site were introduced as fixed effects, and subsamples (specified as interaction of management practice and site) were specified as a random effect. The sub-sampling within management treatment approach allowed for the observed spatial segregation of grazed plots within the sites and enabled testing of the main effects of management and site. This design did not allow for detection of interaction between management and site. Models were fitted using the nlme package (Pinheiro et al. 2016).

Residuals were checked for normality (residuals plots) and heteroscedasticity (Q-Q plots, Bartlett and Levene tests), and data were transformed when needed using logtransformation for a few abundance, evenness, and diversity models, logit-transformation for some abundance models (Warton and Hui 2011), and in one instance (abundance of species of conservation concern) with square-root transformation. Residuals were checked for spatial autocorrelation (Moran's I) and statistical models were updated accordingly with the spatial correlation term in the only instance where it was needed (the model of abundance of species of conservation concern). To estimate effects of management practice and site on provider groups, a robust ANOVA procedure was applied on the LMMs, in which we specified type II errors and we used a heteroscedasticity-corrected coefficient covariance matrix in the event of unequal variances that could not be detected due to low sample size using the (car package, Fox and Weisberg 2011). This approach computes $\chi^{2}$ tests for the fixed effects in the mixed effects models. In addition, we performed pairwise comparisons of the three management categories using post hoc TukeyKramer honest significant difference tests, robust against low and unequal sample sizes using the multcomp package (Hothorn et al. 2008). 


\section{Results}

210 species were recorded from a total of 45 plots across the two study sites. Of these, 127 $(60 \%)$ species were identified as pollen providers, 43 (20\%) species as nectar providers, $36(17 \%)$ species as providers of medicinal or aromatic compounds, $26(12 \%)$ species were endemic or red listed species, $20(10 \%)$ species provided quality fodder and $18(9 \%)$ species were nitrogen fixers. A total of 162 species (77\%) exhibited at least one attribute of interest and over a third (76 species, 36\%) of these species contributed to more than one provider group. All provider groups except for the conservation concern group were represented by at least one species within each $1 \mathrm{~m}^{2}$ plot. We first outline the overall species diversity and abundance differences due to management and site and then present results for individual provider groups.

\section{Effects of management and site on total diversity and abundance of species}

Overall species richness was significantly higher in mowed than grazed plots, while species diversity was significantly higher in abandoned plots than in grazed plots. Total vegetation cover (abundance) was significantly higher in mowed and grazed plots compared with

Table 2 Summary of effect of management and site on total diversity and abundance of species

\begin{tabular}{|c|c|c|c|c|c|}
\hline Response & $\begin{array}{l}\text { Management } \\
\text { action or site }\end{array}$ & $\begin{array}{l}\text { Effect size } \\
(\text { mean } \pm \text { SD) }\end{array}$ & $\begin{array}{l}\text { Tukey test, } \\
p\end{array}$ & $\begin{array}{l}\text { Management or site } \chi^{2} \\
(1, N=45)\end{array}$ & $\begin{array}{l}\text { Management } \\
\text { or site } p\end{array}$ \\
\hline \multirow[t]{5}{*}{ Richness } & Abandoned $^{\mathrm{a}, \mathrm{b}}$ & $33.3 \pm 5.0$ & & & \\
\hline & Grazed $^{\mathrm{a}}$ & $32.1 \pm 5.1$ & $0.02(\mathrm{G}-\mathrm{M})$ & 8.13 & 0.02 \\
\hline & Mowed $^{\mathrm{b}}$ & $36.4 \pm 5.8$ & & & \\
\hline & $\operatorname{Kolos}^{\mathrm{a}}$ & $35.7 \pm 5.5$ & - & 14.51 & $<0.001$ \\
\hline & Somlyób & $30.2 \pm 3.2$ & & & \\
\hline \multirow[t]{5}{*}{ Evenness } & Abandoned & $0.2 \pm 0.05$ & & & \\
\hline & Grazed & $0.2 \pm 0.03$ & $>0.78$ & 0.45 & 0.80 \\
\hline & Mowed & $0.2 \pm 0.04$ & & & \\
\hline & Kolos & $0.2 \pm 0.03$ & - & 0.67 & 0.41 \\
\hline & Somlyó & $0.3 \pm 0.1$ & & & \\
\hline \multirow[t]{5}{*}{ Diversity } & Abandoned $^{\mathrm{a}}$ & $6.1 \pm 1.2$ & & & \\
\hline & Grazed $^{\mathrm{b}}$ & $5.2 \pm 1.4$ & $\begin{array}{l}<0.01 \text { (G- } \\
\text { A) }\end{array}$ & 6.68 & 0.04 \\
\hline & Mowed $^{\text {ab }}$ & $5.6 \pm 1.5$ & & & \\
\hline & $\operatorname{Kolos}^{\mathrm{a}}$ & $4.7 \pm 0.4$ & - & 28.99 & $<0.001$ \\
\hline & Somlyób & $4.0 \pm 0.4$ & & & \\
\hline \multirow[t]{5}{*}{ Abundance } & Abandoned $^{\mathrm{a}}$ & $88.3 \pm 8.8$ & & & \\
\hline & Grazed $^{\mathrm{b}}$ & $95.4 \pm 3.7$ & $\begin{array}{c}<0.01(\mathrm{~A}- \\
\mathrm{M}, \mathrm{A}-\mathrm{G})\end{array}$ & 13.5 & $<0.01$ \\
\hline & Mowed $^{\mathrm{b}}$ & $97.0 \pm 5.9$ & & & \\
\hline & Kolos & $92.4 \pm 7.8$ & - & 1.73 & 0.20 \\
\hline & Somlyó & $95.8 \pm 5.7$ & & & \\
\hline
\end{tabular}

Different letters indicate significant differences between arithmetic mean values

$G$ grazed, $M$ mowed, $A$ abandoned 
abandoned plots (Table 2; Fig. S1 in Online Resource). Total species richness and diversity were significantly higher at the high elevation site Kolos compared to the lower elevation site Somlyó (Table 2; Fig. S1 in Online Resource). Species evenness did not differ significantly between management regimes, and total vegetation cover and species evenness did not differ significantly between the two sites (Table 2; Fig. S1 in Online Resource).

\section{Effect of management regime on richness, evenness, and diversity within provider groups}

The effects of management on diversity and abundance within several provider groups diverged from the effects on overall species diversity and abundance and varied depending on the provider group (Figs. 3, S2). Effects of management on species richness were found only for the pollen provider and conservation concern groups. Similarly to the overall results, there was significantly higher species richness within the pollen provider group in mowed $(25.3 \pm 5.3$ mean $\pm 1 \mathrm{SD})$ than in grazed $(20.6 \pm 4.7)$ plots but in contrast to the overall results there was also higher pollen provider species richness in mowed than in abandoned (22.2 \pm 3.7$)$ plots (Tukey tests $\mathrm{p}<0.05$; Management $\chi^{2}(2, \mathrm{~N}=45)=16.6$, $\mathrm{p}<0.001)$. In accordance with the overall effects there was significantly higher richness of species of conservation concern in mowed $(2.6 \pm 2)$ than in grazed $(1.8 \pm 1.6)$ plots but contrary to the overall effects there was also a higher species richness in species of conservation concern in abandoned $(3.1 \pm 1.8)$ than in grazed plots (Tukey tests $\mathrm{p}<0.05$; Management $\left.\chi^{2}(2, \mathrm{~N}=45)=10.7, \mathrm{p}<0.01\right)$.

While no effect of management was found on overall species evenness, there was a significantly higher evenness within the nitrogen fixation group in mowed $(0.9 \pm 0.5)$ than in abandoned plots $(0.4 \pm 0.3)$ (Tukey tests $\mathrm{p}<0.05$; Management $\chi^{2}(1,2)=7.9$, $\mathrm{p}<0.05)$.

Effects of management on species diversity were found only for the conservation concern provider group. In accordance with the overall effects there was significantly higher species diversity within the group of species of conservation concern in abandoned $(2.3 \pm 1.0)$ than in grazed $(1.2 \pm 0.8)$ plots and similarly to the overall effects, species diversity within the group of conservation concern did not differ between mowed and grazed plots (Tukey tests $\mathrm{p}<0.001$; Management $\left.\chi^{2}(2, \mathrm{~N}=45)=16.6, \mathrm{p}<0.001\right)$.

\section{Effect of management regime on relative abundance of provider groups}

Differences in relative abundance were only detected for the fodder and conservation concern provider groups, which responded differently to the three management actions (Figs. 3, S2). In agreement with the overall results, the abundance of species within the quality fodder provider group was significantly higher in grazed $(65 \% \pm 15$ mean $\pm 1 \mathrm{SD})$ than in abandoned $(44 \% \pm 16)$ plots. However, contrary to the overall results, the abundance of species within the quality fodder group did not differ significantly between abandoned and mowed plots (Tukey tests $\mathrm{p}<0.001$; Management $\chi^{2}(2, \mathrm{~N}=45)=17.9$, $\mathrm{p}<0.001)$. There was a significantly higher abundance of species of conservation concern in mowed $(5 \% \pm 6)$ and abandoned $(9 \% \pm 6)$ plots than in grazed $(0.1 \% \pm 0.2)$ plots (Tukey tests $\mathrm{p}<0.001$; Management $\left.\chi^{2}(2, \mathrm{~N}=45)=47.0, \mathrm{p}<0.001\right)$, in contrast to the overall results where total vegetation cover was significantly higher in grazed and mowed plots relative to abandoned plots. 


\section{Management practice}

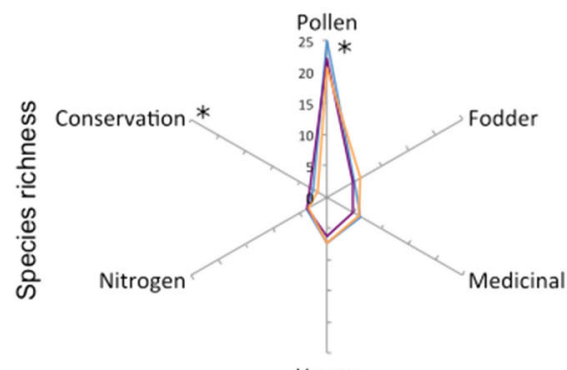

Honey
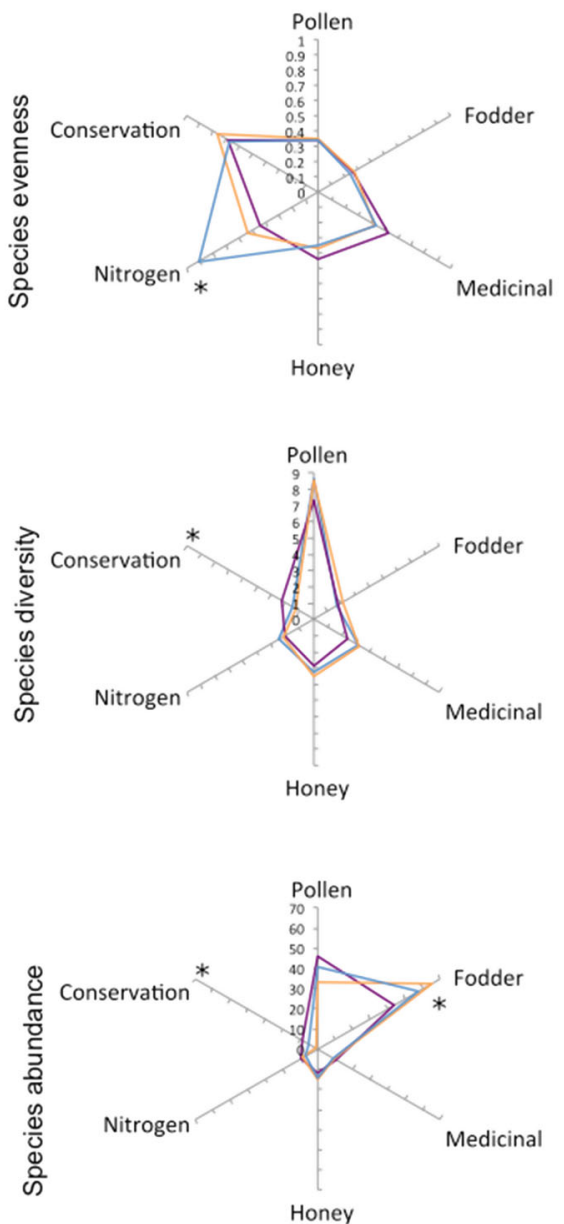

Honey
Site
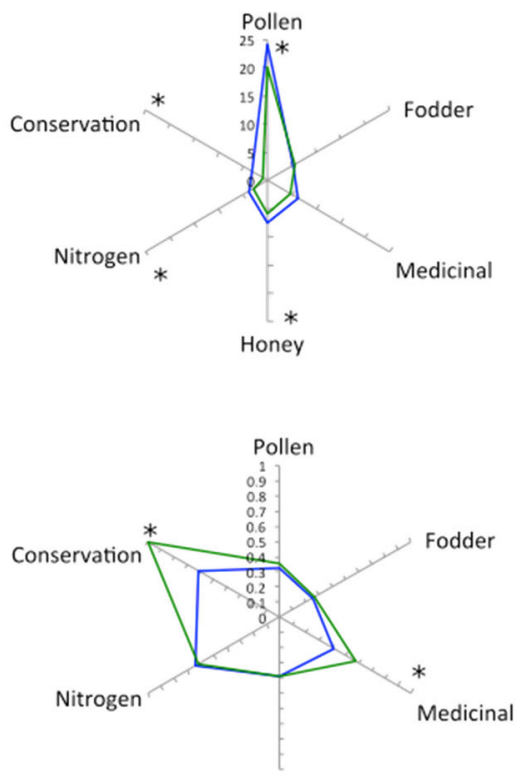

Honey
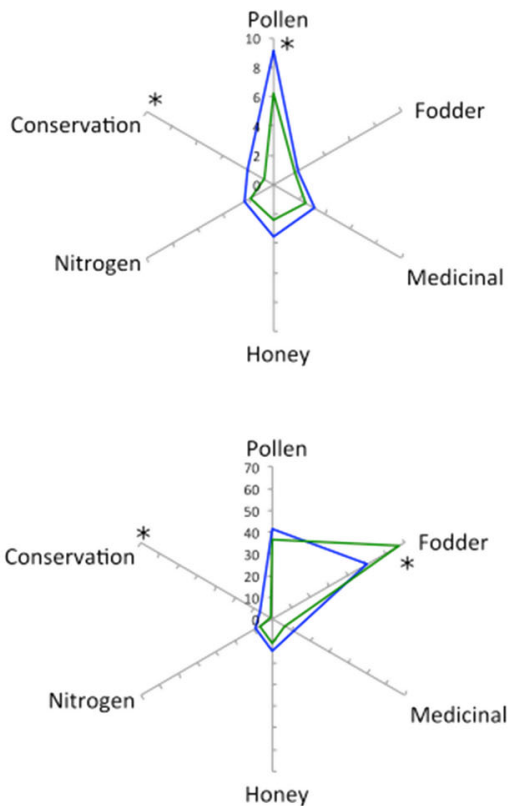
Fig. 3 Species richness, evenness, diversity, and abundance within each provider group (pollen, quality fodder, medicinal and aromatic compound, honey, nitrogen fixation, conservation concern) under three management practices: abandonment of hay meadows (purple line), grazing (orange line), and mowing (light blue line); and sites: higher elevation Kolos (dark blue line) and lower elevation Somlyó, (green line). Stars represent significant management regime and site effects detected with the ANOVA test. Axes represent arithmetic mean of metrics calculated within each $1 \mathrm{~m}^{2}$ plot for each provider group across the three management categories and the two sites

\section{Effect of site on richness, evenness, and diversity within provider groups}

In agreement with the overall effect, there was significantly higher species richness at the high elevation site (Kolos) than at the lower elevation site (Somlyó) within the pollen $\left(24.1 \pm 4.9\right.$ vs. $20.0 \pm 3.6$ mean $\pm 1 \mathrm{SD}$, Site $\left.\chi^{2}(1, \mathrm{~N}=45)=16.0, \mathrm{p}<0.001\right)$; honey $\left(7.6 \pm 2.0\right.$ vs. $5.9 \pm 2.0$, Site $\left.\chi^{2}(1, \mathrm{~N}=45)=8.9, \mathrm{p}<0.01\right)$; nitrogen fixation $\left(4.0 \pm 1.5\right.$ vs. $2.9 \pm 0.7$, Site $\left.\chi^{2}(1, \mathrm{~N}=45)=8.0, \mathrm{p}<0.01\right)$; and species of conservation concern $\left(3.3 \pm 1.7\right.$ vs. $0.9 \pm 0.9$, Site $\left.\chi^{2}(1, \mathrm{~N}=45)=32.0, \mathrm{p}<0.001\right)$ provider groups (Figs. 3, S3). In contrast to the overall effect, species richness within the fodder and medicinal compound provider groups did not differ significantly between the two sites. Whereas no effect of site was found on overall species evenness, species evenness within both the medicinal and aromatic compound $(0.6 \pm 0.2$ vs. $0.4 \pm 0.2)$ and conservation concern $(0.9 \pm 0.3$ vs. $0.6 \pm 0.3)$ provider groups was higher at Somlyó than Kolos sites (Site $\left.\chi^{2}(1, \mathrm{~N}=45)>9.3, \mathrm{p}<0.01\right)$. As with the overall effect, species diversity was also significantly higher at Kolos compared to Somlyó within the pollen $(9.1 \pm 4.0$ vs. $6.2 \pm 2.1$, Site $\left.\chi^{2}(1, N=45) 6.6, p<0.05\right)$ and conservation concern $(2.1 \pm 0.9$ vs. $0.8 \pm 0.7$, Site $\left.\chi^{2}(1, \mathrm{~N}=45)=29.8, \mathrm{p}<0.001\right)$ provider groups, however no effects were detected in the other provider groups.

\section{Effect of site on relative abundance of provider groups}

While no overall effect of site on total vegetation cover was found, the relative cover of the quality fodder provider group was significantly higher at the lower elevation site (Somlyó) than at the high elevation site (Kolos) $\left(67 \pm 17 \%\right.$ vs. $50 \pm 16 \%$ mean $\pm \operatorname{SD}$, Site $\chi^{2}(1$, $\mathrm{N}=45)=15.3, \mathrm{p}<0.001$ ) (Figs. 3, S3), whereas the conservation concern provider group showed the opposite pattern with greater relative cover at Kolos than at Somlyó $\left(7 \pm 6\right.$ vs. $1 \pm 2 \%$, Site $\left.\chi^{2}(1, \mathrm{~N}=45)=34.2, \mathrm{p}<0.001\right)$.

\section{Discussion}

Our testing of the provider group concept illustrates this is a useful approach by which to assess the impacts of management practices on the assumed provision of ecosystem functions and services represented by the provider groups. We found that the effects of management on richness, evenness, diversity, and abundance within provider groups depend on provider group identity, and the presence and direction of these effects do not always correspond with differences in overall species diversity and abundance. Therefore, assessing diversity and abundance changes in response to management for the whole community may not inform on provision of particular functions or services. In addition, the metrics of species richness, evenness, diversity, and abundance responded to management 
differently depending on the provider group, indicating that a suite of indices may be necessary to fully understand the effects of management on each provider group of interest.

The different effects of management can generally be explained by mechanisms that increase or decrease overall species richness and diversity, or favour some species over others. For example, grazing pressure favours species with herbivore avoidance, tolerance or defence mechanisms (Grime 1979), while mowing regimes deplete nutrients from grasslands due to complete biomass removal and enables the persistence of shade-intolerant, fast growing and early season species (Grime 2001; Tilman 1988, 1997; Zobel 1992). If these ecological strategies are not evenly distributed among provider groups then grazing and mowing will differentially affect benefits provided by various provider groups, as evidenced by our study. Several species within the quality fodder provider group avoid or recover rapidly following grazing and were, unsurprisingly, more abundant under a grazing regime (e.g. Trifolium repens, Lolium perenne, Medicago lupulina) while early season species and species sensitive to trampling and nutrient enrichment by livestock, well represented within the pollen and conservation concern provider groups, did better under a mowing than a grazing regime (e.g. Gentiana verna, Gymnadenia conopsea).

Despite the evidence that some species did well under grazing pressure, grasslands managed as hay meadows using traditional techniques (late mowing, no fertilization other than application of manure, no over-sowing, little mechanization) favoured more provider groups (pollen, conservation concern, quality fodder, and nitrogen fixation) than grasslands subjected to intensive grazing (relative to management practices within our study area), which strongly favoured only the quality fodder group. This finding aligns with patterns of reduced diversity under uncontrolled, intensive grazing regimes, particularly by sheep, observed elsewhere in upland Carpathian grasslands (Başnou et al. 2009; Baur et al. 2007). In comparison, abandonment of hay meadows creates conditions more favourable to competitive nutrient-conservative species due to decreased light levels and slowed rates of mineralization and recycling (Jacquemyn et al. 2011; Kahmen and Poschlod 2004; Robson et al. 2007), which disadvantaged some species within the quality fodder group, while a higher diversity of species of conservation concern may be due to a temporary (3-5 years) relaxation of mowing pressure (Huhta and Rautio 1998). However, a longer period of abandonment might result in more dramatic changes in species composition. (Csergő et al. 2013).

The greater diversity and abundance of species of conservation concern found at the higher elevation site was expected because most species in this provider group are confined to higher elevations. Further, the historically low management intensity typical in the more remote areas (Kolos) may have contributed to the retention of naturally higher levels of species diversity, as has been observed elsewhere (Gustavsson et al. 2007). In the lower meadows, historic ploughing between the 1960s-1980s, more frequent mowing, and contemporaneous application of manure could have locally extirpated rare species (e.g. Lathyrus transsylvanicus (Spreng.) Fritsch. and Anemone narcissiflora L.). The frequent application of manure to pastures and hay meadows at the low elevation site (Somlyó) is likely to have contributed to other compositional shifts and thus not all effects observed can be attributed to land management. While we did not test for all factors that might contribute to observed differences between the two study sites, we note that confounding complexities will always accompany dynamic worked landscapes. That we did observe management effects on richness, diversity, evenness, and abundance within provider groups across a heterogeneous landscape illustrates that the presence of interacting effects does not reduce the applicability of the provider group approach. 


\section{Implications of loss of diversity and abundance on the provision of ecosystem services}

Loss in species richness within a provider group can have immediate consequences for the provision of associated ecosystem functions and services (e.g. decreased pollen production by loss of pollen provider species) and cascading impacts, e.g. the loss of pollen provider species from grazed meadows may impact the retention of associated pollinator species within the landscape and disrupt species mutualisms. Management-induced change in abundance of individual species within a provider group can impact on ecosystem service provision if the performance of those species is not substitutable even if only a slight reduction in abundance is detected. Alternatively, provision of ecosystem function and services may continue uninterrupted if a decrease in abundance of one species removes competitive dominance and allows alternative species with the same attribute, and level of performance, to increase in abundance. However, when major shifts in species evenness and diversity occur within the same provider group, important species mutualisms may be discontinued even if the provision of that particular ecosystem service remains uninterrupted.

Thus, it is not only change in diversity and abundance that is relevant to the provision of ecosystem functions and services, but rather which species, or groups of species, experience this change. If loss in species diversity generally is due to the loss of species that were non-contributors to the desired functions or service (e.g. not a pollen provider), the provision of ecosystem function or service could remain uninterrupted. Nonetheless, even seemingly innocuous loss of diversity may in fact be detrimental or have delayed consequences. Species considered as non-contributing may in fact facilitate or complement the processes from contributing species, and their loss may have cascading impacts such as further compositional and functional shifts over time (Laliberté and Tylianakis 2012). Further, response diversity may be lost which would reduce the resilience of the system to environmental change (Laliberté et al. 2010).

\section{Implications for policy and decision making}

Measuring species diversity within provider groups can serve as a useful proxy by which to evaluate the supply of target ecosystem services under various land management regimes. For example, by implementing management practices that are locally favourable to groups of plant species that have high nutritional value to livestock or which are of conservation concern, the production of stock fodder (allowing for food production which is a provisioning ecosystem service) can be sustained alongside the conservation of endemic and/or red listed species (a cultural ecosystem service) at the landscape scale. Alternatively, tradeoffs can be recognized and different management practices can be implemented at different sites to optimise service provision.

There are implications of our work for Romanian and European land management policies. The European Union's (EU) Common Agricultural Policy (CAP, European Commission 2012) utilises agri-environment schemes to support agriculture and sustain biodiversity within the EU. Natura 2000, the largest network of protected areas in the world and a cornerstone policy for biodiversity conservation within the EU also allows for agricultural practices (European Commission 1992, 2009). While both the CAP and Natura 2000 encourage the maintenance of traditional land use practices, neither has been adequate to support traditional small-scale farming specific to East-Central European cultural 
landscapes (Babai et al. 2015; Sutcliffe et al. 2015). For example, under the 2007-2013 format, the CAP agri-environment scheme applicable to High Natural Value grasslands within Romania did not differentiate between mown and grazed grassland systems, instead offering the same level of payment to both practices. As grazing is a less labour intensive and less costly practice, the scheme indirectly favoured grazing over mowing, causing loss in species diversity (Baur et al. 2007; Demeter and Kelemen 2012) and, as we demonstrate here, potential consequences for ecosystem service provision.

Maintaining local populations of species of conservation concern is a key objective of conservation policies. The significant reduction of species richness, diversity, and relative abundance of species of conservation concern under a grazing regime affects the ability to meet these objectives. This can represent a conservation challenge as maintaining grasslands as pastures is a culturally vital aspect of traditional farming practices in the Carpathian Mountains, while mountain hay meadows are protected by EU legislation for maintaining species richness and species of conservation concern (European Commission 1992). The persistence of mountain hay meadows has historically been dependent on traditional pastoralism and a rational distribution of management practices at the landscape level. The diversity of species of conservation concern can therefore conceivably be maintained across the wider landscape under a mosaic of land cover produced by mixeduse that includes pastures, extensively mowed and temporarily abandoned hay meadows, even though populations are likely to decline or disappear at the local scale when subject to intensive grazing.

We suggest that a mixed-management regime will be required to sustain multifunctional landscapes. What constitutes an appropriate mixed-management regime in this or any other landscape will be driven by desired outcomes as defined by stakeholders, decision makers, and existing policies and agreements. Understanding the biophysical realm of ecosystem service provision is crucial for the application of land management aimed to influence ecosystem service provision, but also needs to be incorporated with social concerns to more effectively manipulate both the supply of ecosystem services and the flow to beneficiaries.

While we have not attempted to calculate the level of performance of provider groups in providing ecosystem services under different management practices (e.g. multifunctionality indices, Byrnes et al. 2014), this would be an interesting research question that could add to our provider group approach by quantifying the changes we observed. However, an advantage of our approach is that it explicitly reviews the identity of service change, rather than reducing the provision of ecosystem services into a single metric. In addition we do not apply differential weights to ecosystem services, as to do so would require community input to define values and accepted thresholds of performance (Allan et al. 2015). This could be useful additional work that would allow for a more detailed quantification of trade-offs and synergies in the provision of ecosystem services.

\section{Conclusions}

The provider group approach is a useful and pragmatic method for assessing the impact of management on the provision of ecosystem services using widely available data on species composition and abundance. This approach explicitly links attributes of natural capital stocks with the supply of required ecosystem functions and services and allows for the impacts of management practices to be assessed in this context rather than on diversity per 
se. As the provider group approach is underpinned by species traits, and not reliant on specific species, it is generalisable, and can be applied at both local and landscape scales to inform decision making on the provision of ecosystem services. The provider group can also easily and rapidly be applied post hoc to any dataset that includes species composition and abundance data, collected from any local system, under any land use or management regime with the addition of information on species contributing to different ecosystem services. Analysis can also easily be repeated over time, using alternative provider groups and/or under a different set of policy objectives. This wide application and ease of use makes the provider group approach a readily implementable way to compare the influence of different management regimes on the provision of ecosystem services.

Acknowledgements We thank field assistants Alpár Kelemen and Gabriella Péter. A. M. C and L. D were funded by DG Environment through the European Forum on Nature Conservation and Pastoralism and Barbara Knowles Fund, in collaboration with the Pogány-havas Association, Romania. F. J. F. M was funded by an Australian Research Council Australian Postgraduate Award and an Australian Research Council Centre of Excellence for Environmental Decisions Top-Up Scholarship and also received funding from the New Zealand Ministry of Business, Innovation and Employment funded research partnership project BEST (Building biodiversity into an ecosystem service-based approach for resource management). This publication has emanated from research supported in part by a research grant to YMB from Science Foundation Ireland (SFI) under Grant Number 15/ERCD/2803.

\section{Compliance with ethical standards}

Conflict of interest The authors declare that they have no conflict of interest.

Open Access This article is distributed under the terms of the Creative Commons Attribution 4.0 International License (http://creativecommons.org/licenses/by/4.0/), which permits unrestricted use, distribution, and reproduction in any medium, provided you give appropriate credit to the original author(s) and the source, provide a link to the Creative Commons license, and indicate if changes were made.

\section{References}

Allan E, Weisser W, Weigelt A, Roscher C, Fischer M, Hillebrand H (2011) More diverse plant communities have higher functioning over time due to turnover in complementary dominant species. Proc Natl Acad Sci USA 108:17034-17039. doi:10.1073/pnas.1104015108

Allan E et al (2015) Land use intensification alters ecosystem multifunctionality via loss of biodiversity and changes to functional composition. Ecol Lett 18:834-843

Babai D, Molnár Z (2014) Small-scale traditional management of highly species-rich grasslands in the Carpathians Agriculture. Ecosyst Environ 182:123-130

Babai D et al (2015) Do conservation and agri-environmental regulations effectively support traditional small-scale farming in East-Central European cultural landscapes? Biodivers Conserv 24:3305-3327

Başnou C, Pino J, Šmilauer P (2009) Effect of grazing on grasslands in the Western Romanian Carpathians depends on the bedrock type. Preslia 81:91-104

Baur B, Cremene C, Groza G, Schileyko A, Baur A, Erhardt A (2007) Intensified grazing affects endemic plant and gastropod diversity in alpine grasslands of the Southern Carpathian mountains (Romania). Biologia 62:438-445

Byrnes JEK et al (2014) Investigating the relationship between biodiversity and ecosystem multifunctionality: challenges and solutions. Methods Ecol Evol 5:111-124

Cadotte MW, Carscadden K, Mirotchnick N (2011) Beyond species: functional diversity and the maintenance of ecological processes and services. J Appl Ecol 48:1079-1087

Csergő AM, Demeter L, Turkington R, Cahill JF (2013) Declining diversity in abandoned grasslands of the Carpathian Mountains: do dominant species matter? PLoS ONE 8:e73533

Csűrös Ş, Csűrös-Káptalan M, Resmeriţă, I (1970) Indicii ecologici: umiditate, temperatură, reacţia solului şi valoarea furajeră a celor mai importante specii din pajiştile Transilvaniei, II., Studia Univ. BabeşBolyai Biol 1:9-14 
Csűrös I, Csűrös M, Pálfalvi P (1980) A Csíki-havasok néhány növénytársulásának ökológiai jellemzése (Ecological characters of the vegetation of Munţii Ciucului). Acta Hargit 27:417-432

Demeter L, Kelemen A (2012) Quantifying the abandonment of mountain hay meadows in the Eastern Carpathians. England

Díaz S, Cabido M (2001) Vive la différence: plant functional diversity matters to ecosystem processes. Trends Ecol Evol 16:646-655

Duncan C, Thompson JR, Pettorelli N (2015) The quest for a mechanistic understanding of biodiversityecosystem services relationships. Proc R Soc B Biol Sci. doi:10.1098/rspb.2015.1348

European Commission (1992) The Habitats Directive Council Directive 92/43/EEC of 21 May 1992 on the conservation of natural habitats and of wild fuana and flora

European Commission (2009) The Birds Directive Council Directive 2009/147/EC of the European Parliament and of the Council of 30 November 2009 on the conservation of wild birds

European Commission (2012) The Common agricultural policy. A partnership between Europe and Farmers. European Commission, Luxembourg

Fox J, Weisberg S (2011) An R companion to applied regression, 2nd edn. Sage Publications, Thousand Oaks. http://socserv.socsci.mcmaster.ca/jfox/Books/Companion/

Gamfeldt L et al (2013) Higher levels of multiple ecosystem services are found in forests with more tree species. Nat Commun 4:1340

Grime JP (1979) Plant strategies and vegetation processes. Wiley, Chichester

Grime JP (2001) Plant strategies, vegetation processes and ecosystem properties, 2nd edn. Wiley, Chichester

Gustavsson E, Lennartsson T, Emanuelsson M (2007) Land use more than 200 years ago explains current grassland plant diversity in a Swedish agricultural landscape. Biol Conserv 138:47-59

Hautier Y, Seabloom EW, Borer ET, Adler PB, Harpole WS, Hillebrand H, Lind EM, MacDougall AS, Stevens CJ, Bakker JD, Buckley YM, Chu C, Collins SL, Daleo P, Damschen EI, Davies KF, Fay PA, Firn J, Gruner DS, Jin VL, Klein JA, Knops JMH, La Pierre KJ, Li W, McCulley RL, Melbourne BA, Moore JL, O'Halloran LR, Prober SM, Risch AC, Sankaran M, Schuetz M, Hector A (2014) Eutrophication weakens stabilizing effects of diversity in natural grasslands. Nature 508:521-525

Hodgson D, McDonald JL, Hosken DJ (2015) What do you mean, 'resilient'? Trends Ecol Evol 30:503-506

Hothorn T, Bretz F, Westfall P (2008) Simultaneous inference in general parametric models. Biom J 50:346-363

Huhta A-P, Rautio P (1998) Evaluating the impacts of mowing: a case study comparing managed and abandoned meadow patches. In: Annales Botanici Fennici. JSTOR, pp 85-99

Isbell F, Calcagno V, Hector A, Connolly J, Harpole WS, Reich PB, Scherer-Lorenzen, Schmid B, Tilmans D, van Ruijven J, Weigelt A, Wilsey BJ, Zavaleta ES, Loreau M (2011) High plant diversity is needed to maintain ecosystem services. Nature 477:199-202

Jacquemyn H, Van Mechelen C, Brys R, Honnay O (2011) Management effects on the vegetation and soil seed bank of calcareous grasslands: an 11-year experiment. Biol Conserv 144:416-422

Kahmen S, Poschlod P (2004) Plant functional trait responses to grassland succession over 25 years. J Veg Sci 15:21-32

Knowles B (2011) Mountain hay meadows: the Romanian context and the effects of policy on high nature value farming. In: Knowles B (ed) Mountain hay meadows: hotspots of biodiversity and traditional culture. Society of Biology. Pogány-Havas Association, London

Laliberté E, Tylianakis JM (2012) Cascading effects of long-term land-use changes on plant traits and ecosystem functioning. Ecology 93:145-155

Laliberté E et al (2010) Land-use intensification reduces functional redundancy and response diversity in plant communities. Ecol Lett 13:76-86

Lavorel S et al (2011) Using plant functional traits to understand the landscape distribution of multiple ecosystem services. J Ecol 99:135-147

Luck GW et al (2009) Quantifying the contribution of organisms to the provision of ecosystem services. Bioscience 59:223-235

Mace GM, Norris K, Fitter AH (2012) Biodiversity and ecosystem services: a multilayered relationship. Trends Ecol Evol 27:19-26

Naeem S, Wright JP (2003) Disentangling biodiversity effects on ecosystem functioning: deriving solutions to a seemingly insurmountable problem. Ecol Lett 6:567-579

Oksanen J et al. (2013) vegan: community ecology package. R package ver. 2.0-10

Oltean M, Negrean G, Popescu A, Roman N, Dihoru G, Sanda V, Mihailescu S (1994) Lista roşie a plantelor superioare din România vol 1. Institutul de biologie, studii, sinteze, documentaţii de ecologie, Bucuresti

Oprea A (ed) (2005) Lista critică a plantelor vasculare din România. Alexandru loan Cuza Univerisitatea, Iaşi 
Pinheiro J, Bates D, DebRoy S, Sarkar D, R Core Team (2016) nlme: linear and nonlinear mixed effects models. R package version 3.1-128. http://CRAN.R-project.org/package=nlme

R Core Team (2015) R: a language and environment for statistical computing. R Foundation for Statistical Computing, Vienna

Robson TM, Lavorel S, Clement J-C, Le Roux X (2007) Neglect of mowing and manuring leads to slower nitrogen cycling in subalpine grasslands. Soil Biol Biochem 39:930-941

Sanda V, Öllerer K, Burescu P (2008) Fitocenozele din România. Sintaxonomie, structură, dinamică şi evoluție. Ars Docendi, Universitatea din Bucureşti, București

Smith B, Wilson JB (1996) A consumer's guide to evenness indices. Oikos 70-82

Sutcliffe LM et al (2015) Harnessing the biodiversity value of Central and Eastern European farmland. Divers Distrib 21:722-730

Tilman D (1988) Plant strategies and the dynamics and structure of plant communities, vol 26. Princeton University Press, Princeton

Tilman D (1997) Community invasibility, recruitment limitation, and grassland biodiversity. Ecology 78:81-92

Wagg C, Bender SF, Widmer F, van der Heijden MGA (2014) Soil biodiversity and soil community composition determine ecosystem multifunctionality. Proc Natl Acad Sci USA 111:5266-5270

Warton DI, Hui FKC (2011) The arcsine is asinine: the analysis of proportions in ecology. Ecology 92:3-10

Wilson JB, Peet RK, Dengler J, Pärtel M (2012) Plant species richness: the world records. J Veg Sci 23:796-802

Zobel M (1992) Plant species coexistence: the role of historical, evolutionary and ecological factors. Oikos 314-320 